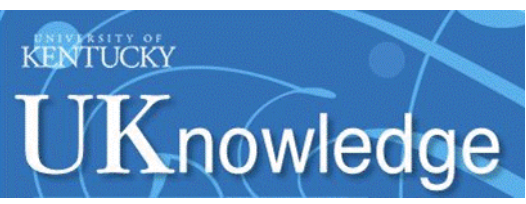

University of Kentucky

UKnowledge

$5-2000$

\title{
Solute Transport as Related to Soil Structure in Unsaturated Intact Soil Blocks
}

\author{
L. Bejat \\ Clemson University \\ E. Perfect \\ University of Kentucky \\ V. L. Quisenberry \\ Clemson University \\ Mark S. Coyne \\ University of Kentucky, mark.coyne@uky.edu \\ G. R. Haszler \\ University of Kentucky
}

Follow this and additional works at: https://uknowledge.uky.edu/pss_facpub

Part of the Plant Sciences Commons

Right click to open a feedback form in a new tab to let us know how this document benefits you.

\section{Repository Citation}

Bejat, L.; Perfect, E.; Quisenberry, V. L.; Coyne, Mark S.; and Haszler, G. R., "Solute Transport as Related to Soil Structure in Unsaturated Intact Soil Blocks" (2000). Plant and Soil Sciences Faculty Publications. 10. https://uknowledge.uky.edu/pss_facpub/10

This Article is brought to you for free and open access by the Plant and Soil Sciences at UKnowledge. It has been accepted for inclusion in Plant and Soil Sciences Faculty Publications by an authorized administrator of UKnowledge. For more information, please contact UKnowledge@lsv.uky.edu. 


\section{Solute Transport as Related to Soil Structure in Unsaturated Intact Soil Blocks}

Digital Object Identifier (DOI)

http://dx.doi.org/10.2136/sssaj2000.643818x

\section{Notes/Citation Information}

Published in Soil Science Society of America Journal, v. 64, no. 3, p. 818-826.

The copyright holder has granted the permission for posting the article here. 
Kakubo, A., S. Matsukawa, and H. Katoh. 1995. Effects of nitrate solution on soil permeability and salts leaching. (in Japanese with English summary) Trans. Jap. Soc. Irrigation, Drainage Reclamation Eng. 180:103-110.

Karube, J., K. Nakaishi, H. Sugimoto, and M. Fujihira. 1992. Electrophoretic behavior of imogolite under alkaline conditions. Clays Clay Miner. 40:625-628.

Karube, J., K. Nakaishi, H. Sugimoto, and M. Fujihira. 1996. Size and shape of allophane particles in dispersed aqueous systems. Clays Clay Miner. 44:485-491.

Karube, J. 1998. Hysteresis of the colloidal stability of imogolite. Clays Clay Miner. 46:583-585.

Karube, J., H. Sugimoto, M. Fujihira, and K. Nakaishi. 1998. Stability and charge characteristics of allophane and imogolite. (in Japanese with English summary) Trans. Jap. Soc. Irrigation, Drainage Reclamation Eng. 196:103-110.

Keren, R., and M.J. Singer. 1988. Effect of low electrolyte concentration on hydraulic conductivity of sodium/calcium-montmorillonitesand system. Soil Sci. Soc. Am. J. 52:368-373.

Marsh, K.B., R.W. Tillman, and J.K. Syers. 1987. Charge relationships of sulfate sorption by soils. Soil Sci. Soc. Am. J. 51:318-323.

Matsukawa, S., H. Tomita, S. Suzuki, and H. Katoh. 1998. Relation between soil dispersion, hydraulic conductivity and $\mathrm{pH}$ of soil water for allophanic soils during acid solution leaching. (in Japanese with English summary) Soil Physical Conditions and Plant Growth Japan. 77:3-9.

McNeal, B.L., and N.T. Coleman. 1966. Effect of solution composition on soil hydraulic conductivity. Soil Sci. Soc. Am. Proc. 30:308-312.
Nakagawa, T., and Ishiguro. 1994. Hydraulic conductivity of an allophanic andisol as affected by solution pH. J. Environ. Qual. 23: 208-210.

National Institute of Agricultural Sciences. 1984. Outline of the test of soil and the major nutrients in the field of the National Institute of Agricultural Sciences. (in Japanese) Materials of Department of Chemistry, Natl. Inst. Agric. Sci. 3:1-32

Okamura, Y., and K. Wada. 1983. Electric charge characteristics of horizons of Ando (B) and Red-Yellow B soils and weathered pumices. J. Soil Sci. 34:287-295.

Quirk, J.P., and R.K. Schofield. 1955. The effect of electrolyte concentration on soil permeability. J. Soil Sci. 6:163-178.

Rajan, S.S.S. 1979. Adsorption and desorption of sulfate and charge relationships in allophanic clays. Soil Sci. Soc. Am. J. 43:65-69.

Shainberg, I., J.D. Rhoades, and R.J. Prather. 1981. Effect of low electrolyte concentration on clay dispersion and hydraulic conductivity of a sodic soil. Soil Sci. Soc. Am. J. 45:273-277.

Shainberg, I., and M.J. Singer. 1990. Soil response to saline and sodic conditions. p. 91-112. In K.K. Tanji (ed.) Agricultural salinity assessment and management. Am. Soc. Civil Eng.

Suarez, D.L., J.D. Rhoades, R. Lavado, and C.M. Grieve. 1984. Effect of $\mathrm{pH}$ on saturated hydraulic conductivity and soil dispersion. Soil Sci. Soc. Am. J. 48:50-55.

Yousaf, M., O.M. Ali, and J.D. Rhoades. 1987. Clay dispersion and hydraulic conductivity of some salt-affected arid land soils. Soil Sci. Soc. Am. J. 51:905-907.

\title{
Solute Transport as Related to Soil Structure in Unsaturated Intact Soil Blocks
}

\author{
L. Bejat, E. Perfect, V. L. Quisenberry,* M. S. Coyne, and G. R. Haszler
}

\begin{abstract}
Concern about soil and groundwater pollution has resulted in numerous studies focused on solute transport. The objectives of our study were to investigate the effect of soil type and land-use management on solute movement. Transport of water and $\mathrm{Cl}^{-}$were measured through intact blocks of Maury (fine, mixed, semiactive, mesic Typic Paleudalf) and Cecil (fine, kaolinitic, thermic Typic Kanhapludult) soils, under steady-state, unsaturated flow conditions. Three replicate blocks for the Maury soil and two replicate blocks for the Cecil soil were studied per land-use treatment. The land-use treatments were conventional-till corn (Zea mays $\mathbf{L}$.) production and long-term grass pasture. Individual blocks were instrumented with time domain reflectometry (TDR) probes at the 5-, 15-, and 25-cm depths. The effluent $\mathrm{Cl}^{-}$and TDR breakthrough curves were fitted using the convection dispersion equation (CDE); the estimated parameters were pore water velocity $(v)$, dispersion coefficient $(D)$, and, for the TDR breakthrough curves, maximum bulk electrical conductivity $\left(\mathrm{BEC}_{\max }\right)$. The CDE fitted the data very well, with model $R^{2}$ values ranging from 0.971 to 0.999 . Volumetric water content $(\theta)$, total porosity, the soil water retention curve, and saturated hydraulic conductivity were determined on the same blocks. Volumetric water content increased $\left(R^{2}=0.25\right)$ as the slope of the water retention curve decreased. Increasing $\theta$ resulted in decreasing $v\left(R^{2}=0.20\right)$ and thus, because of the linear relationship between $D$ and $v\left(R^{2}=0.26\right)$, decreasing $D$. Structural controls on solute dispersion in this study were mainly indirect, and related to variations in water content produced by differences in pore-size distribution.
\end{abstract}

L. Bejat and V.L. Quisenberry, Dep. of Crop and Soil Environmental Sciences, Clemson Univ., Clemson, SC 29634; E. Perfect, M.S. Coyne, and G.R. Haszler, Dep. of Agronomy, University of Kentucky, Lexington, KY 40546. Received 1 Mar. 1999. *Corresponding author (vqsnbrr@clemson.edu).

Published in Soil Sci. Soc. Am. J. 64:818-826 (2000).
$\mathrm{C}$ ONCERN ABOUT SOIL AND GROUNDWATER POLLUTION has resulted in numerous studies focused on solute transport. The dispersion of a nonreactive solute can be related to soil structural form and water content (Seyfried and Rao, 1987). Poletika and Jury (1994) suggested two processes by which solutes and water become spatially variable in structured soil. One is the lateral movement and redistribution of the input solution on the soil surface; the other is the movement of solute through macropores. Patterns of localized macropore flow vary with antecedent moisture content, rainfall intensity, soil type and morphology, tillage practice, and earthworm (Lumbricus terrestris) activity (Andreini and Steenhuis, 1990; Shipitalo et al., 1990; Edwards et al., 1992; Granovsky et al., 1993; Quisenberry et al., 1994). Recent studies examining macropore influences on solute transport through intact soil blocks indicate that flow paths are spatially variable (Quisenberry et al., 1994; Wildenschild et al., 1994).

Quisenberry et al. (1994) found that more than onehalf of the total drainage occurred through just 12 to $19 \%$ of the soil cross-sectional area. For any given leaching event, surface-applied solutes can elute from constantly changing locations in the soil profile. Flow path stability may be related to soil structural stability. Till-

Abbreviations: ANOVA, analysis of variance; CDE, convection dispersion equation; MIM, mobile-immobile model; TDR, timedomain reflectometry. 
age practices influence soil structure and transport processes. Tillage destroys the natural pore structure of surface soils, disrupting macropore continuity, and reducing the extent of bypass flow. Increased infiltration rates in no-till fields have been attributed to the greater number and continuity of macropores in the surface layer compared with moldboard-plowed soils (Edwards et al., 1988; Dick et al., 1989). Reduced macropore flow may promote increased adsorption of agricultural chemicals in soil. This could delay the onset of groundwater contamination from individual storms.

Numerous studies have summarized the results of fitting transport parameters to tracer experiments (e.g., Parker and van Genuchten, 1984; Jury and Sposito, 1985; Kool et al., 1987, Beven et al., 1993). Flow through macropores can be considered part of a continuum of flow velocities that may be quantified using the classical CDE (Parker and van Genuchten, 1984). However, miscible displacement experiments conducted on undisturbed samples often reveal substantial deviations between observed breakthrough curves and those predicted by the CDE (Kay and Elrick, 1967; Nielsen et al., 1986; Jardine et al., 1988). Two-region mobileimmobile models (MIM) were developed to address these discrepancies (Rao et al., 1980a, b; van Genuchten and Dalton, 1986). Stochastic-convective models have also been used to predict the solute movement in structured soils. The most widely used of the latter type is the convective-lognormal transfer function described by Jury (1982).

Relationships between transport parameters and variables such as flow rate were reported by Biggar and Nielsen, (1976), Bowman and Rice (1986), and Dyson and White (1987). However, there is no currently accepted model for the influence of water content on solute dispersion under steady-state unsaturated flow conditions. Several researchers working with simplified glass bead systems have noted that the slope of the relationship between $D$ and the mean $v$ appears to be steeper under unsaturated conditions than under saturated conditions (e.g., De Smedt and Wierenga, 1984; Matsubayashi et al., 1997; Haga et al., 1999). These studies imply that the dispersivity $(\alpha=D / v)$ depends on the degree of saturation. In contrast, the results of Yule and Gardner (1978) suggest that dispersivity is independent of water content and is determined exclusively by pore space geometry. Yule and Gardner (1978) worked with packed beds of Plainfield sand (mixed, mesic Typic Udipsamment). They found a wide range in dispersivity at any given flow rate. The variability in estimates of $D$ increases significantly with undisturbed samples from structured soils (Beven et al., 1993). Given such variability, it is unlikely that the relationship between $D$ and $v$ can be shown to be statistically different under saturated and unsaturated flow conditions for heterogeneous porous media.

Relatively few experimental studies have been conducted in which the solute breakthrough curve and structural characteristics were determined on the same undisturbed samples, thereby permitting the establishment of an empirical relationship between dispersivity and pore-size distribution. Anderson and Bouma (1977) observed greater $\mathrm{Cl}^{-}$dispersion in undisturbed soil samples with subangular blocky structure than in samples with a prismatic structure. Walker and Trudgill (1983) reported significant correlations between solute transport parameters and several pore geometry variables measured by image analysis of soil thin sections. Gist et al. (1990) showed that tracer dispersion in consolidated rocks was a function of the width of the pore-size distribution determined by $\mathrm{Hg}$ porosimetry. Recently, Vervoort et al. (1999) related dispersivities determined under saturated conditions to the width of the pore-size distribution, as inferred from the slope of the soil water retention curve (Vervoort et al., 1999).

Our study combined measurements of soil water content, structural properties, and solute breakthrough in order to investigate methods of predicting transport parameters independently. Solute transport was measured through relatively large, undisturbed soil blocks under steady-state, unsaturated flow conditions. The main objectives of the study were to investigate (i) how soil type and land-use management practices affected the solute movement and (ii) how soil water content and structural properties are related to transport parameters.

\section{MATERIALS AND METHODS \\ Soil Blocks}

Six 0.325 by 0.325 by $0.325 \mathrm{~m}$ deep soil blocks were obtained from a Maury silt loam soil at the University of Kentucky Spindletop Experiment Station. Four soil blocks with the same dimensions were obtained from a Cecil sandy loam soil at the Clemson University Simpson Experimental Station. Selected soil properties for the Maury and Cecil soils are given in Table 1. Three replicate blocks for the Maury soil and two replicate blocks for the Cecil soil were studied per land-use treatment. The land-use treatments were conventional-till (disk) corn production and long-term grass pasture.

The soil blocks were excavated, encased in polyurethane foam, and transported to the laboratory according to the meth-

Table 1. Selected soil properties for the untilled soils.

\begin{tabular}{|c|c|c|c|c|c|c|c|}
\hline Soil & Depth & $\begin{array}{l}\text { Organic } \\
\text { matter }\end{array}$ & pH & CEC $\dagger$ & Sand & Silt & Clay \\
\hline & $\mathrm{cm}$ & $\%$ & & $\mathrm{cmol}_{\mathrm{c}} \mathbf{k g}^{-1}$ & 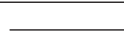 & $\%$ & 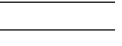 \\
\hline Maury & $\begin{array}{r}0-15 \\
15-30\end{array}$ & $\begin{array}{l}5.6-7.7 \\
2.5-2.6\end{array}$ & $\begin{array}{l}5.0-5.2 \\
5.6-5.8\end{array}$ & $\begin{array}{r}10.0-15.2 \\
7.1-14.7\end{array}$ & $\begin{array}{l}8.1-22.1 \\
6.0-8.2\end{array}$ & $\begin{array}{l}60.3-69.4 \\
66.5-68.0\end{array}$ & $\begin{array}{l}17.6-22.5 \\
25.3-26.0\end{array}$ \\
\hline Cecil & $\begin{array}{r}0-10 \\
10-20 \\
20-30\end{array}$ & $\begin{array}{l}1.8-2.1 \\
1.4-2.1 \\
0.8-0.9\end{array}$ & $\begin{array}{l}6.0-6.2 \\
5.8-6.4 \\
6.0-6.1\end{array}$ & $\begin{array}{l}7.4-10.3 \\
5.9-8.8 \\
8.8-17.6\end{array}$ & $\begin{array}{l}51.8-61.7 \\
51.1-64.8 \\
22.2-37.9\end{array}$ & $\begin{array}{l}15.4-14.8 \\
15.6-16.0 \\
12.8-15.3\end{array}$ & $\begin{array}{l}23.5-32.8 \\
19.6-32.9 \\
49.3-62.4\end{array}$ \\
\hline
\end{tabular}

$\dagger$ Cation-exchange capacity. 
ods of Shipitalo et al. (1990), Bowman et al. (1994), and Quisenberry et al. (1994). We encased the soil blocks in plywood on four sides and poured liquid polyurethane foam into the gap between the soil block and the wood casing. The polyurethane foam was left to cure overnight. We separated the soil blocks from the rest of the soil $\approx 10 \mathrm{~cm}$ from the bottom of the casing and transported the blocks to a temperature-controlled room for storage at $4^{\circ} \mathrm{C}$. All blocks were covered in plastic to ensure that the soil would not dry, crack or pull away from the foam interface during storage. We trimmed the bottom of each individual soil block flush with the wood casing, placed the block on a collection chamber, and caulked it with silicon to make an airtight and waterproof seal.

The top of the collection chamber was a metal grid consisting of 144 cells in a 12 by 12 array that collected drainage from the block. The collection cells were 3.05 by $3.05 \mathrm{~cm}$ and tapered to a 3-mm-diameter drain hole at the bottom. Nylon screens (Nitex 53- $\mu \mathrm{m}$ mesh, Sefar America, Briarcliff Manor, NY) were placed in the bottom of each cell and the cells were filled with a saturated, $100-\mu \mathrm{m}$-diameter glass bead phase barrier placed between the soil and the collection chamber.

The outermost row of cells collected the outflow from the soil-foam interface. All results in this study are based on effluent collected from only the 100 innermost collection cells. Therefore, any possible effects of edge flow were minimized. Plastic trays held 100 plastic centrifuge tubes $(50-\mathrm{mL}$ volume) beneath the drain holes of the collection cells to collect soil block drainage. Drainage from the outermost row of cells was collected in a separate tray. The procedures for installing a soil block on this collection chamber are described in detail by Quisenberry et al. (1994). A -2.0-kPa vacuum was applied to the lower boundary of each soil block via the collection chamber (Phillips et al., 1995). Based on the capillary equation (Danielson and Sutherland, 1986), this vacuum drained all pores greater than 0.15 -mm equivalent cylindrical diameter.

\section{Transport Experiments}

Simulated rainfall was applied to the top of each block at a target rate of $1 \mathrm{~cm} \mathrm{~h}^{-1}\left(1056 \mathrm{~mL} \mathrm{~h}^{-1}\right)$. The simulator was a square reservoir, 32 by 32 by $5 \mathrm{~cm}$, constructed of acrylic plastic $0.32 \mathrm{~cm}$ thick. It was positioned $20 \mathrm{~cm}$ above the soil block. One hundred hypodermic needles, $0.25 \mathrm{~mm}$ in diameter, were used for the rainfall application (Quisenberry et al., 1994). The rainfall simulator actually applied fluxes in the range of 0.64 to $1.00 \mathrm{~cm} \mathrm{~h}^{-1}$; the average value was $0.85 \mathrm{~cm}$ $\mathrm{h}^{-1}$. When steady flow was achieved, the influent solution was changed from $0.003 \mathrm{~mol} \mathrm{~L}^{-1} \mathrm{CaSO}_{4}$ to $0.03 \mathrm{~mol} \mathrm{~L}^{-1} \mathrm{KCl}$ to produce a step increase in solute concentration.

Each experiment lasted $36 \mathrm{~h}$. Fifteen trays of effluent were collected: 11 trays of 50-mL tubes collecting effluent from individual drain holes alternated with four bulk trays (all leachate collected en mass). The bulk trays collected the drainage water after 12, 20, 24, and $32 \mathrm{~h}$. Two subsamples were taken to determine the $\mathrm{Cl}^{-}$concentration. The tube trays were changed at the end of each hour, except Trays 5, 7, and 15, which were run for a 4 -h period. The trays with tubes were checked regularly for cells with high flow, and individual tubes were replaced once full. The $50-\mathrm{mL}$ tubes were weighed to determine leachate volume in each cell, and this value was converted into a flux $\left(\mathrm{cm} \mathrm{h}^{-1}\right)$. The $\mathrm{Cl}^{-}$concentration $\left(\mathrm{mg} \mathrm{L}^{-1}\right)$ was measured using a Bio-Tech EL-311 microplate autoreader (Biotech Instruments, Luton, UK) by the automated ferricyanide method (American Public Health Association, 1989). Relative $\mathrm{Cl}^{-}$concentrations $\left(C / C_{0}\right)$ were determined as a function of time for each block by dividing the flux averaged effluent $\mathrm{Cl}^{-}$concentration $(C)$ by the concentration of the influent $\mathrm{Cl}^{-}\left(C_{0}\right)$.

Time-domain reflectometry was used to measure $\theta$ and $\mathrm{BEC}$ in situ during each experiment. The TDR method is rapid and nondestructive (Baker and Allmaras, 1990). By measuring changes in $\mathrm{BEC}$ with time in response to a change in influent solution concentration, it is possible to determine a resident concentration breakthrough curve at exactly the same location where $\theta$ is measured (Hart and Lowery, 1998). Each soil block was instrumented with 20 -cm-long TDR wave guides installed horizontally at the 5-, 15-, and 25 -cm depths. The wave guides were connected to a Tektronix 1502C cable tester (Tektronix, Beaverton, OR) via a multiplexer. Data were collected automatically, and the waveforms were analyzed for $\theta$ and BEC with software developed by Wraith et al. (1993). The $\theta$ s within the soil blocks were extremely stable for the course of the 36-h experiment and were therefore averaged over time for each depth. Resident concentration breakthrough curves were calculated from the BEC data by the following relationship:

$$
\frac{C}{C_{0}}=\frac{\mathrm{BEC}-\mathrm{BEC}_{\text {initial }}}{\mathrm{BEC}_{\max }-\mathrm{BEC}_{\text {initial }}}
$$

where $\mathrm{BEC}_{\text {initial }}$ is the bulk electrical conductivity measured prior to the step change in solution concentration, and $\mathrm{BEC}_{\max }$ is the maximum bulk electrical conductivity attained when breakthrough is complete.

Once the breakthrough data were obtained, they were parameterized using the $\mathrm{CDE}$. For the transport of $\mathrm{Cl}^{-}$, the two principal fitting parameters of the CDE are $D$ and $v$. These parameters are often combined to give the dispersivity $(\alpha)$, defined as $\alpha=D / v$. The dimensionless column Peclet number (van Genuchten and Wierenga, 1986), defined as $P=L / \alpha$ (where $\mathrm{L}$ is the depth where the breakthrough curves were measured), was also calculated.

The CXTFIT computer program (Parker and van Genuchten, 1984; Toride et al., 1995) was used to estimate the solute transport parameters of the soil blocks. CXTFIT has an inverse capability that can estimate $D$ and $v$ from the observed results of a solute transport experiment. The program uses a nonlinear least squares fitting procedure to optimize the fit between the observed data and the CDE. Flux averaged relative concentrations were used as inputs in the CXTFIT program for the effluent $\mathrm{Cl}^{-}$data. For the TDR resident concentration data, $\mathrm{BEC}$ in Eq. [1] was the input, with $\mathrm{BEC}_{\text {initial }}$ specified and $\mathrm{BEC}_{\max }$ treated as a fitting parameter. All data were fitted in terms of the equilibrium CDE, with CXTFIT 2.0 in Mode 1 (Mode code $=1$ was deterministic equilibrium CDE).

\section{Soil Structural Characterization}

After each experiment, the soil blocks were drained overnight, removed from the collection chamber and triplicate soil cores $(5.7 \mathrm{~cm}$ in diam. by $6 \mathrm{~cm}$ long) were taken from the 5-, $15-$, and $25-\mathrm{cm}$ depths. These cores were used to determine the bulk density and the soil water retention (drying) curve (Klute, 1986). Tempe cells were used to collect the retention data between tensions of 0 and $3 \mathrm{kPa}$, and pressure plate apparatuses were used to collect the corresponding data between 3 and $1500 \mathrm{kPa}$ (Klute and Dirksen, 1986). Total porosity was calculated from the bulk density data, assuming a particle density of $2.65 \mathrm{~g} \mathrm{~cm}^{-3}$. The soil water retention curves were parameterized using the empirical model developed by Campbell (1974). The estimated parameters in this model are $\psi_{\mathrm{a}}$, the air-entry value, and $b$ the pore-size distribution index. Coefficients of determination $\left(R^{2}\right)$ for the fits ranged from 0.77 to 0.99 .

The cores were also used to determine the saturated hydrau- 
Table 2. Comparison of means for bulk density, volumetric water content, and water retention parameters.

\begin{tabular}{|c|c|c|c|c|c|c|}
\hline Soil & Treatment & Depth & $\begin{array}{c}\text { Bulk } \\
\text { density }\end{array}$ & $\begin{array}{c}\text { Volumetric } \\
\text { water content }\end{array}$ & $\begin{array}{l}\text { Air entry } \\
\text { value }\end{array}$ & $\begin{array}{r}\text { Pore-size } \\
\text { distributio }\end{array}$ \\
\hline & & cm & $\mathrm{g} \mathrm{cm}^{-3}$ & $\mathbf{m}^{3} \mathbf{m}^{-3}$ & $\mathbf{k P a}$ & \\
\hline \multirow{6}{*}{ Maury } & Tillage & 5 & $1.01(0.02) \dagger$ & $0.20(0.03)$ & $0.07(0.02)$ & $8.79(0.13)$ \\
\hline & Tillage & 15 & $1.30(0.04)$ & $0.35(0.02)$ & $0.35(0.16)$ & $12.2(0.32$ \\
\hline & Tillage & 25 & $1.35(0.08)$ & $0.33(0.01)$ & $1.15(0.83)$ & $12.7(1.28)$ \\
\hline & Sod & 5 & $1.17(0.02)$ & $0.33(0.06)$ & $0.33(0.33)$ & 13.5 \\
\hline & Sod & 15 & $1.34(0.03)$ & $0.35(0.03)$ & 0.54 (0.16) & $13.3(0.65$ \\
\hline & Sod & 25 & $1.33(0.06)$ & $0.33(0.01)$ & $0.50(0.33)$ & $12.6(2.65)$ \\
\hline \multirow[t]{6}{*}{ Cecil } & Tillage & 5 & $1.38(0.06)$ & $0.25(0.02)$ & $0.42(0.07)$ & $5.29(0.22)$ \\
\hline & Tillage & 15 & $1.63(0.07)$ & $0.28(0.04)$ & $0.28(0.15)$ & $9.13(1.24)$ \\
\hline & Tillage & 25 & $1.50(0.24)$ & $0.29(0.03)$ & 1.27 (1.21) & 16.9 (1.64) \\
\hline & Sod & 5 & $1.38(0.26)$ & $0.30(0.05)$ & $0.08(0.01)$ & $8.21(1.70)$ \\
\hline & Sod & 15 & $1.61(0.02)$ & $0.31(0.06)$ & $0.42(0.48)$ & 10.4 (3.77) \\
\hline & Sod & 25 & 1.33 (0.19) & $0.36(0.05)$ & $0.28(0.01)$ & 14.9 (3.61) \\
\hline
\end{tabular}

$\dagger$ Mean value with standard deviation in parentheses.

lic conductivity $\left(K_{\text {sat }}\right)$. These measurements were carried out using the constant head method, as described in Klute and Dirksen (1986). Saturated hydraulic conductivity data were collected at each depth for sod Block 3 and tilled Block 3 of the Maury soil and for all four Cecil soil blocks.

\section{Data Analysis}

Geostatistical analyses were performed by computing indicator variograms $(1=$ flowing, $0=$ nonflowing $)$ for the individual fluxes for each block. The results indicated little or no spatial structure, so the data were analyzed using conventional statistical procedures, including analysis of variance (ANOVA) and regression analysis (SAS Institute, 1988). The overall statistical design was: two soils (Maury, Cecil), two land-use treatments (conventional-till, pasture), three depths $(5,15,25 \mathrm{~cm})$, and three replicates. Data for the third replicate of the Cecil soil were treated as missing values. For the effluent transport parameters depth was not a factor. Three determinations were made per replicate for the soil structural properties; these values were averaged prior to performing the ANOVAs. Statistical significance was assessed at the $P<0.01$ and $P<0.05$ probability levels.

Correlation analyses were performed for each block between the spatial distribution of fluxes in Tray 1 (Hour 1) and the spatial distribution in Tray 15 (Hour 36) for both Maury and Cecil soils.

Linear regression analyses were performed on all of the data in order to evaluate relationships between the soil water contents, structural characteristics and solute transport parameters. Only those relationships that were significant at $P<$ 0.05 or greater will be reported.

\section{RESULTS AND DISCUSSION Soil Properties}

Mean values for the soil water content and structural properties are presented as a function of soil type, landuse treatment, and depth in Table 2. Soil bulk density varied with soil type and depth. On average, the bulk density of the Maury soil was significantly lower than that of the Cecil soil $(P<0.05)$. The mean value of bulk density at $5 \mathrm{~cm}$ was significantly lower than the mean values at the other two depths in both soils $(P<$ $0.05)$. There was no effect of land use on bulk density.

Mean values of $\theta$ ranged from 0.2 to $0.35 \mathrm{~cm}^{3} \mathrm{~cm}^{-3}$ for the Maury blocks and from 0.25 to $0.36 \mathrm{~cm}^{3} \mathrm{~cm}^{-3}$ for the Cecil blocks (Table 2). Analysis of variance indi- cated significant depth and treatment (land use) effects on the water contents $(P<0.05)$ (Table 3$)$. The sodcovered blocks had significantly higher $\theta$ than the tilled blocks, and $\theta$ increased with depth for both soils (Maury and Cecil), and both land-use treatments (sod and tilled).

The parameters estimated from fitting the Campbell (1974) equation to the soil water retention data, the airentry value $\left(\psi_{\mathrm{a}}\right)$, and pore-size distribution index $(b)$, are summarized in Table 2 . The air-entry value greatly increased with increasing depth for the tilled blocks, but increased only slightly with increasing depth for the sodcovered blocks. This trend may be due to loosening of the surface soil and subsurface compaction (i.e., a plow pan) in the tilled blocks compared with the sod-covered blocks. However, because of variability in the data (the coefficient of variation was $95 \%$ ), the ANOVA for this parameter was not significant (Table 3).

In contrast to $\psi_{\mathrm{a}}$, the $b$ parameter was much more predictable, with a coefficient of variation of $15.2 \%$. Soil, depth, the soil $\times$ depth interaction, and the landuse treatment $\times$ depth interaction were all significant factors influencing $b$ at $P<0.05$ (Table 3). The Maury soil has a significantly higher mean $b$ value than the Cecil soil. The $b$ value increased with increasing depth for the Cecil soil in both treatments, but showed an increase with depth only for the tilled Maury soil (Table $2)$. The $b$ parameter is an indicator of pore-size distribution; for large values of $b$, small pores dominate the total porosity, and vice versa.

Values for the saturated hydraulic conductivities

Table 3. Analysis of variance results for bulk density, water content, air-entry value, and pore size-distribution index.

\begin{tabular}{lcccc}
\hline & \multicolumn{4}{c}{$F$ value } \\
\cline { 2 - 5 } Sources of variation & $\begin{array}{c}\text { Bulk } \\
\text { density }\end{array}$ & $\begin{array}{c}\text { Water } \\
\text { content }\end{array}$ & $\begin{array}{c}\text { Air-entry } \\
\text { value }\end{array}$ & $\begin{array}{c}\text { Pore-size } \\
\text { distribution }\end{array}$ \\
\hline Model & $\mathbf{6 . 1 6} * *$ & $3.99 * *$ & 1.64 & $\mathbf{7 . 1 9}^{* *}$ \\
Soil & $\mathbf{3 0 . 1}^{* *}$ & $\mathbf{1 . 4 5}$ & $\mathbf{0 . 0 4}$ & $\mathbf{4 . 5 6}^{*}$ \\
Treatment & $\mathbf{0 . 0 1}$ & $\mathbf{1 0 . 8} * *$ & $\mathbf{1 . 8 6}$ & $\mathbf{4 . 1 6}$ \\
Soil $\times$ treatment & 2.36 & $\mathbf{0 . 0 4}$ & $\mathbf{0 . 9 2}$ & $\mathbf{0 . 8 4}$ \\
Depth & $\mathbf{1 1 . 8} * *$ & $\mathbf{6 . 5 3} * *$ & $\mathbf{4 . 0 6}$ & $\mathbf{2 1 . 9} * *$ \\
Soil $\times$ depth & $\mathbf{3 . 3 0}$ & $\mathbf{2 . 0 4}$ & $\mathbf{0 . 0 6}$ & $\mathbf{1 2 . 6} * *$ \\
Treatment $\times$ depth & $\mathbf{1 . 4 5}$ & $\mathbf{2 . 3 7}$ & $\mathbf{3 . 1 4}$ & $4.57^{*}$ \\
Soil $\times$ treatment $\times$ depth & $\mathbf{0 . 1 8}$ & $\mathbf{2 . 4 3}$ & $\mathbf{0 . 2 2}$ & $\mathbf{0 . 2 8}$ \\
$\boldsymbol{R}^{2}$ & $\mathbf{0 . 7 9}$ & $\mathbf{0 . 7 1}$ & $\mathbf{0 . 5 0}$ & $\mathbf{0 . 8 2}$ \\
\hline
\end{tabular}

*, ** Significant at the 0.05 and 0.01 levels of probability, respectively. 


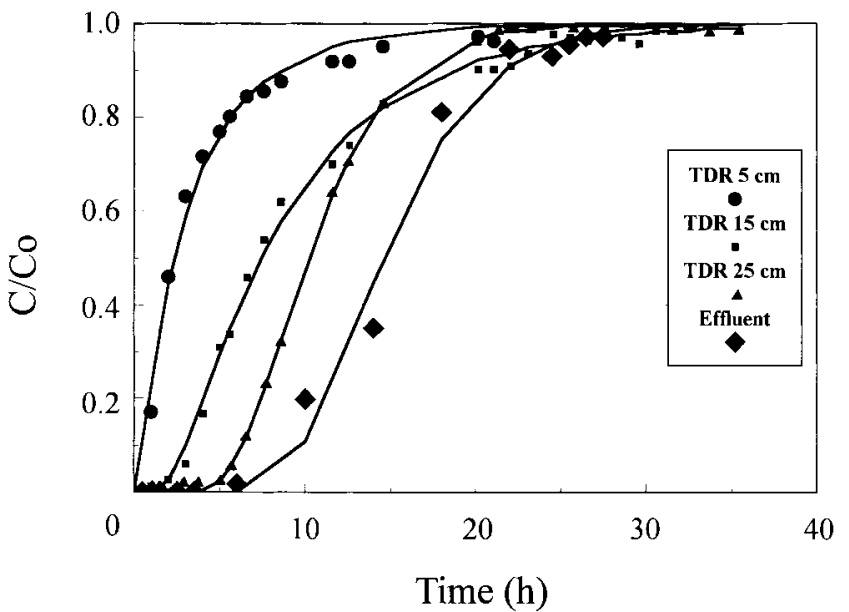

Fig. 1. Breakthrough curves for time domain reflectometry (TDR) and effluent data for Maury tilled soil (Block 1).

ranged from $8 \times 10^{-5}$ to $8 \times 10^{-3} \mathrm{~m} \mathrm{~s}^{-1}$ for the Maury soil blocks, and from $4 \times 10^{-4}$ to $5 \times 10^{-3} \mathrm{~m} \mathrm{~s}^{-1}$ for the Cecil soil blocks. Due to missing values an ANOVA could not be performed on these data. However, the data for the Maury soil indicate that the tilled block had higher surface $K_{\text {sat }}$ values than the sod-covered soil. The land-use effect was much less pronounced for the Cecil soil, which generally appeared to have decreasing $K_{\text {sat }}$ values with increasing depth regardless of management history. This trend can probably be attributed to the marked increase in clay content with depth for this soil.

\section{Individual Cell Fluxes}

For the Maury sod blocks, an average of 33\% of cells collected leachate with a mean flux of $2.67 \mathrm{~cm} \mathrm{~h}^{-1}$, while the Maury tilled blocks averaged $38 \%$ of cells collecting leachate, with a mean flux of $3.48 \mathrm{~cm} \mathrm{~h}^{-1}$. These results indicate that the sod blocks had a slightly more concentrated spatial flow pattern than the tilled blocks. The opposite trend was observed for the Cecil soil. For the Cecil tilled blocks, the mean percentage of cells collecting drainage water was $40 \%$ and the mean flux was 2.23

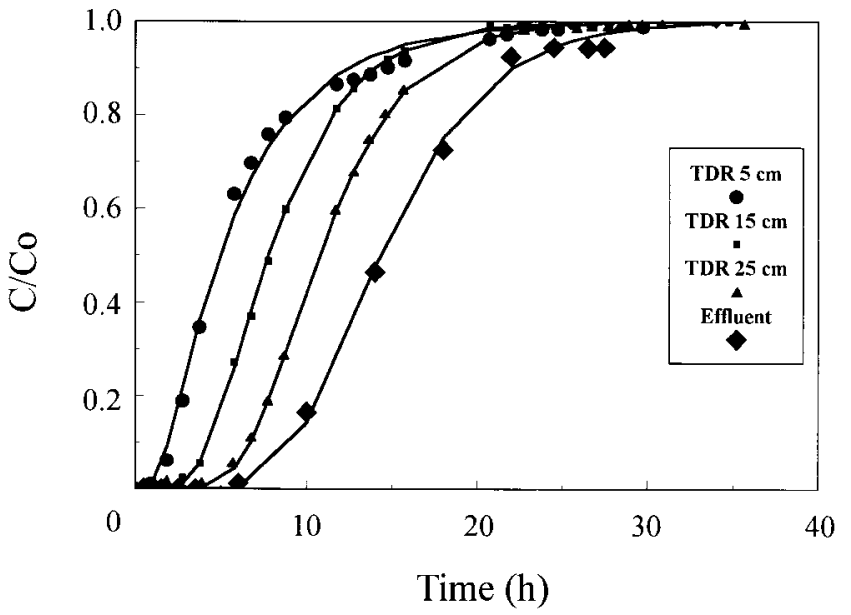

Fig. 2. Breakthrough curves for time domain reflectometry (TDR) and effluent data for Maury sod covered soil (Block 3).

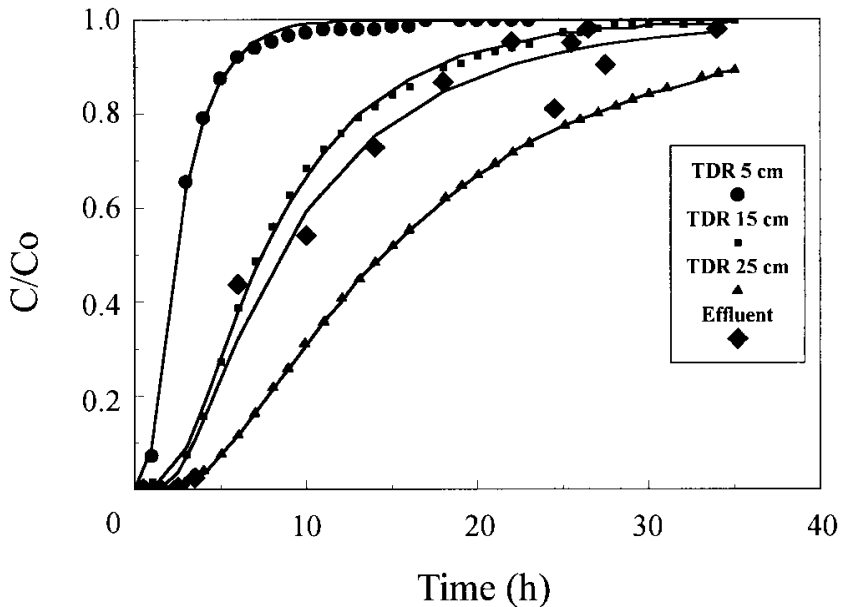

Fig. 3. Breakthrough curves for time domain reflectometry (TDR) and effluent data for Cecil tilled soil (Block 2).

$\mathrm{cm} \mathrm{h}^{-1}$. For the Cecil sod blocks, the mean percentage of cells was $50 \%$ with a slightly lower mean flux of 1.96 $\mathrm{cm} \mathrm{h}^{-1}$.

The correlation analyses, performed for each block, between the spatial distribution of fluxes in Tray 1 (Hour 1) and the spatial distribution in Tray 15 (Hour 36) provided a measure of the temporal stability of the flow pattern (from the start of the experiment to completion). Although the mean correlation coefficients $r$ values) were not significantly different at $P<0.05$ between the two Maury treatments, the tilled blocks had a lower mean $r$ value $(r=0.65)$ than the sod blocks $(r=0.73)$. The higher $r$ value for the sod blocks indicates a more stable flow pattern from start to finish than for the tilled blocks. For the Cecil soil, although the correlation coefficients for the two land-use treatments were not significantly different $(P<0.05)$, the Cecil tilled blocks had a lower mean $r$ value $(r=0.44)$ than the Cecil sod blocks $(r=0.61)$. The higher mean $r$ value for the sod blocks shows a more steady and even flow rate from start to finish, while the lower mean $r$ value for the tilled blocks indicates a more temporally variable flow pattern.

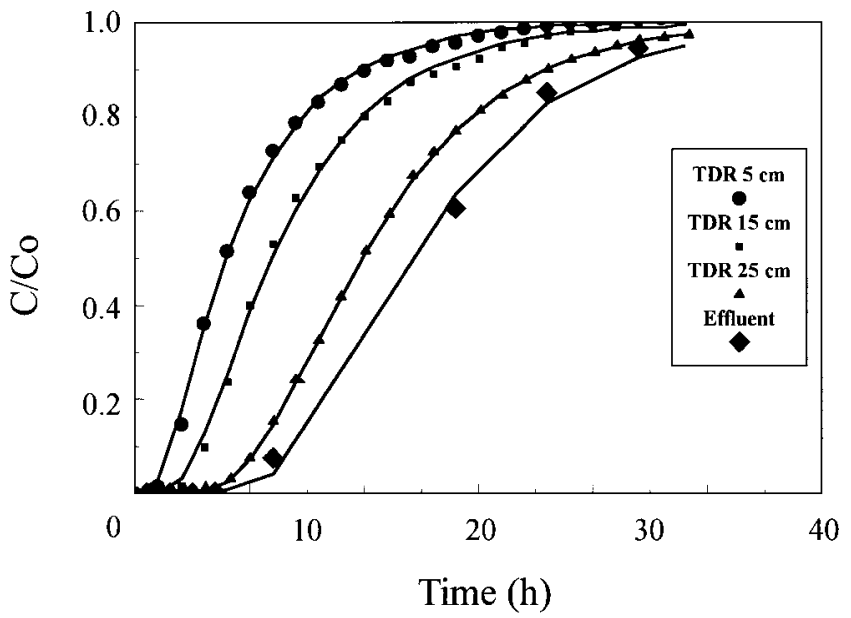

Fig. 4. Breakthrough curves for time domain reflectometry (TDR) and effluent data for Cecil sod covered soil (Block 2). 
Table 4. Comparison of means for solute transport parameters from effluent breakthrough curves.

\begin{tabular}{|c|c|c|c|c|c|}
\hline Soil & Treatment & $\begin{array}{l}\text { Pore water } \\
\text { velocity }\end{array}$ & $\begin{array}{l}\text { Dispersion } \\
\text { coefficient }\end{array}$ & Dispersivity & $\begin{array}{c}\text { Peclet } \\
\text { number }\end{array}$ \\
\hline & & $\mathbf{c m ~ h} \mathbf{h}^{-1}$ & $\mathbf{c m}^{2} \mathbf{h}^{-1}$ & cm & \\
\hline Maury & $\begin{array}{l}\text { Tillage } \\
\text { Sod }\end{array}$ & $\begin{array}{l}2.21(0.18) \dagger \\
1.97(0.27)\end{array}$ & $\begin{array}{l}3.34(2.65) \\
6.64(2.34)\end{array}$ & $\begin{array}{l}1.46(1.07) \\
3.43(1.31)\end{array}$ & $\begin{array}{l}44.1(47.2) \\
10.8(5.29)\end{array}$ \\
\hline Cecil & $\begin{array}{l}\text { Tillage } \\
\text { Sod }\end{array}$ & $\begin{array}{l}2.77(0.25) \\
2.20(0.36)\end{array}$ & $\begin{array}{l}20.1 \\
20.8(19.1)\end{array}$ & $\begin{array}{l}7.70(9.41) \\
10.2(10.3)\end{array}$ & $\begin{array}{l}16.7(20.4) \\
6.39(6.43)\end{array}$ \\
\hline
\end{tabular}

$\dagger$ Mean value with standard deviation in parentheses.

Tillage affects soil aggregation; in the absence of a protective cover like sod, aggregates are vulnerable to disruption by flowing water (Hillel, 1980). As aggregates collapse and flow lines change, the fluxes for some cells might change with time, while the overall flow rate for the block remains fairly constant from Tray 1 to Tray 15. The sod-covered soil had an accumulation of organic matter so that aggregates in this treatment should have been more stable than in the tilled soil. Greater aggregate stability would be expected to result in more stable flow patterns with time, as indicted by the higher $r$ values for the sod vs. tilled blocks. The lower mean $r$ values for the Cecil soil, relative to the Maury soil, may indicate a lower aggregate stability for this soil as compared with Maury soil.

\section{Solute Breakthrough Curves}

The breakthrough and the fitted curves of representative TDR and effluent data are presented in Fig. 1 to 4. The CDE fitted the observed breakthrough curves very well, with $R^{2}$ values ranging from 0.971 to 0.999 . The average $R^{2}$ was 0.988 . Because of the goodness of fit obtained with the CDE, the MIM model was not employed in this study.

The effluent breakthrough curves represent the flowweighted average relative $\mathrm{Cl}^{-}$concentrations. These curves have some advantages and limitations relative to the resident breakthrough curves obtained by TDR. One principal advantage is that the effluent concentrations were normalized with respect to a well-known input solution concentration. In contrast, the TDR BEC data had to be normalized with respect to estimates of their own late-time values. However, the TDR data were collected more frequently than effluent concentration data, and by automated methods.
The 5-cm TDR probe was the first one to increase after the step increase in applied water conductivity (Fig. 1-4). Subsequent increases were registered at the $15-$ and $25-\mathrm{cm}$ probe depths. The curves take on a more sigmoid shape as the solute moves farther from the source and deeper into the soil block. For most of the cases, the effluent breakthrough curve is increasing at later times compared with the TDR breakthrough curves. An exception was the Cecil tilled soil (Fig. 3), where the $25-\mathrm{cm}$ depth TDR breakthrough curve was observed later than the effluent breakthrough curve. This may be due to the relative insensitivity of TDR resident concentrations to macropore flow. Previous field and laboratory experiments, with undisturbed Cecil soils, have shown that areas $>50 \%$ of the total crosssectional area within the $\mathrm{Bt}$ horizon have little or no flow at all, even after two or three pore volumes of solute have been eluted (Hatfield, 1988; Nelson, 1990). The TDR probes at the $25-\mathrm{cm}$ depth in Fig. 3 may well have been located within such a zone.

\section{Transport Parameters}

The $D$ and $\alpha$ values for the Cecil soil and sod treatment were generally greater than the corresponding values for the Maury soil and tillage treatment, respectively (Table 4). However, the variation around these mean values was too high (see Table 4) to establish any statistically significant differences. The ANOVA results on the transport parameters for the effluent data showed no significant effects of soil type and land use on $v, D$, $\alpha$, and Peclet number.

Analyses of variance and mean values for the TDRdetermined transport parameters are presented in Tables 5 and 6, respectively. As expected for these constant target flux experiments, there were no significant effects

Table 5. Comparison of means for solute transport parameters from time domain reflectometry breakthrough curves.

\begin{tabular}{|c|c|c|c|c|c|c|}
\hline Soil & Treatment & Depth & $\begin{array}{c}\text { Pore water } \\
\text { velocity }\end{array}$ & $\begin{array}{l}\text { Dispersion } \\
\text { coefficient }\end{array}$ & Dispersivity & $\begin{array}{c}\text { Peclet } \\
\text { number }\end{array}$ \\
\hline & & $\mathbf{c m}$ & $\mathbf{c m ~ h} \mathbf{h}^{-1}$ & $\mathbf{c m}^{2} \mathbf{h}^{-1}$ & $\mathbf{c m}$ & \\
\hline \multirow[t]{6}{*}{ Maury } & Tillage & 5 & $2.70(0.63) \dagger$ & $13.9(6.81)$ & 4.96 (1.29) & $1.05(0.27)$ \\
\hline & Tillage & 15 & $2.01(0.21)$ & $6.49(4.24)$ & 3.12 (1.88) & $6.27(3.90)$ \\
\hline & Tillage & 25 & $2.17(0.34)$ & 3.66 (1.52) & $1.63(0.49)$ & $16.5(5.99)$ \\
\hline & Sod & 5 & $1.34(0.31)$ & $6.03(6.49)$ & 3.96 (3.50) & 1.93 (1.15) \\
\hline & Sod & 15 & $1.71(0.24)$ & $3.51(0.83)$ & $2.11(0.74)$ & 7.65 (2.31) \\
\hline & Sod & 25 & $1.90(0.38)$ & $5.17(2.97)$ & $2.89(2.06)$ & $11.4(5.95)$ \\
\hline \multirow[t]{6}{*}{ Cecil } & Tillage & 5 & $1.77(0.58)$ & $2.67(0.45)$ & $1.54(0.25)$ & $3.27(0.54)$ \\
\hline & Tillage & 15 & $2.10(0.00)$ & $9.11(0.00)$ & $4.33(0.00)$ & $3.45(0.00)$ \\
\hline & Tillage & 25 & $1.77(0.08)$ & $18.1(2.57)$ & 10.2 (1.94) & $2.48(0.47)$ \\
\hline & Sod & 5 & $1.37(0.07)$ & $1.53(1.05)$ & $1.13(0.83)$ & 5.97 (4.36) \\
\hline & Sod & 15 & $2.06(0.74)$ & $6.40(3.12)$ & $3.03(0.41)$ & $4.99(0.67)$ \\
\hline & Sod & 25 & $2.14(0.56)$ & $8.15(0.02)$ & 3.95 (1.05) & $6.56(1.75)$ \\
\hline
\end{tabular}

$\dagger$ Mean value with standard deviation in parentheses. 
Table 6. Analysis of variance results for pore water velocity, dispersion coefficient, dispersivity and Peclet number from the time domain reflectometry breakthrough curves.

\begin{tabular}{|c|c|c|c|c|}
\hline \multirow[b]{2}{*}{ Sources of variation } & \multicolumn{4}{|c|}{$F$ value } \\
\hline & $\begin{array}{l}\text { Pore water } \\
\text { velocity }\end{array}$ & $\begin{array}{l}\text { Dispersion } \\
\text { coefficient }\end{array}$ & Dispersivity & $\begin{array}{l}\text { Peclet } \\
\text { number }\end{array}$ \\
\hline Model & 2.12 & 3.51* & $4.13 * *$ & $4.41^{*}$ \\
\hline Soil & 0.41 & 0.61 & 1.88 & $4.85^{*}$ \\
\hline Treatment & 4.26 & $6.52 *$ & $4.67 *$ & 0.46 \\
\hline Soil $\times$ treatment & 3.69 & 0.23 & 3.19 & 1.82 \\
\hline Depth & 0.61 & 1.37 & 2.90 & $7.54 * *$ \\
\hline Soil $\times$ depth & 1.36 & $11.3 * *$ & $12.7 * *$ & 7.74** \\
\hline Treatment $\times$ depth & 3.20 & 0.11 & 0.71 & 0.29 \\
\hline Soil $\times$ treatment $\times$ depth & 0.36 & 3.40 & 3.89* & 1.04 \\
\hline$R^{2}$ & 0.58 & 0.69 & 0.73 & 0.74 \\
\hline
\end{tabular}

*, ** Significant at the 0.05 and 0.01 levels of probability.

of soil type, land use, or depth on $v$ (Table 6). In contrast, the ANOVA results for $D$ indicated that land-use treatment $(P<0.05)$, and the soil $\times$ depth interaction $(P<0.01)$ were both significant effects (Table 6). The dispersion coefficient $(D)$ decreased with increasing depth for the Maury soil and increased with increasing depth for the Cecil soil (Table 5). This result can be related to differences in soil texture and structure as a function of depth in these soils. The Cecil soil consists of coarse-textured material overlying much finer material. Furthermore, the structural units of a Cecil Bt horizon are usually larger than those found in the Bt horizon of a Maury soil. The Cecil soil has primary, secondary, and tertiary units (Brewer, 1976).

Dispersivities followed a similar trend to $D$ (Table 5). However, the triple interaction term was also significant (Table 6), indicating no significant effect of depth on $\alpha$ under Maury sod. Thus, the depth effects discussed above only hold for the tilled soil in the case of $\alpha$. Results of ANOVA for the column Peclet number identified soil $(P<0.05)$, depth, and the soil $\times$ depth interaction $(P<0.01)$ as significant effects (Table 6). The Peclet number increased with increasing depth in the Maury soil, but showed no consistent trend with depth in the Cecil soil (Table 5). This result is due to the consistent increase in $D$ with depth observed in the Cecil soil.

\section{Relationships between Transport Parameters and Soil Properties}

The regression analyses performed on all the data evaluated relationships between the soil water contents,

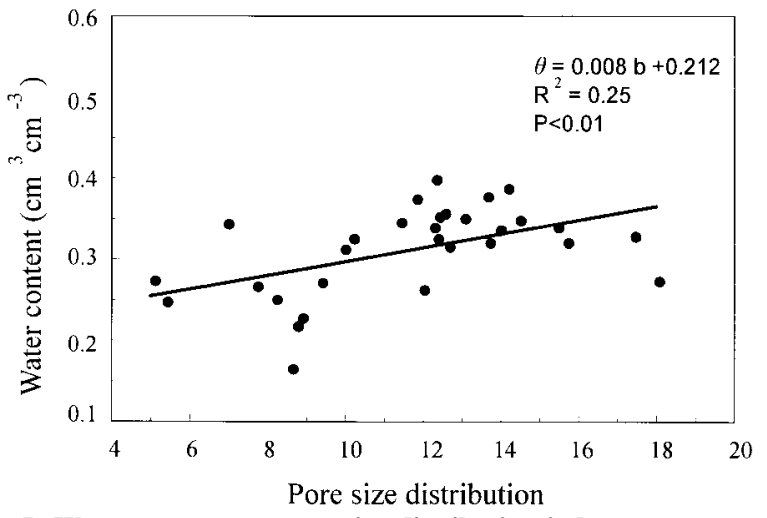

Fig. 5. Water content vs. pore-size distribution index. structural characteristics, and solute transport parameters. For the steady-state, unsaturated flow conditions employed in this study, the $\theta$ increased as the Campbell $b$ parameter increased (Fig. 5). This is because under unsaturated conditions more water is retained by soil with many small pores (and a large $b$ value) than soil with few small pores (and small $b$ value) at any given flow rate. For a constant water flux, the mean $v$ should decrease with increasing water content. The expected result is apparent in Fig. 6, although the $R^{2}$ value was quite low.

Numerous studies have described relationships between $D$ and $v$. The dispersivity parameter assumes a linear relationship between $D$ and $v$. However, some studies have modeled the relationship between $D$ and $v$ as a power law, in the form: $D=D_{0}+m v^{n}$, where $m$ and $n$ are fitting parameters and $D_{0}$ is the effective diffusion coefficient. Biggar and Nielsen (1976) reported a strong relationship for this model $\left(R^{2}=0.79\right)$, with $n=1.1$. Bowman and Rice (1986) found weaker relationships, with $n$ values ranging from 1.42 to 2.2. Other studies reported that correlations between $D$ and $v$ can be highly variable and in some cases apparently negative (Van Ommen et al., 1989).

In this study, the relationship between $D$ and $v$ was approximately linear, with $D$ increasing with increasing $v$ (Fig. 7). Because of the linear relationship between $D$ and $v, D$ also decreased with increasing water content (Fig. 8), indicating increased solute dispersion at low water contents as compared with high water contents, at the same flux. This result suggests an indirect influence of $b$ on $D$ through the relationship between $\theta$ and

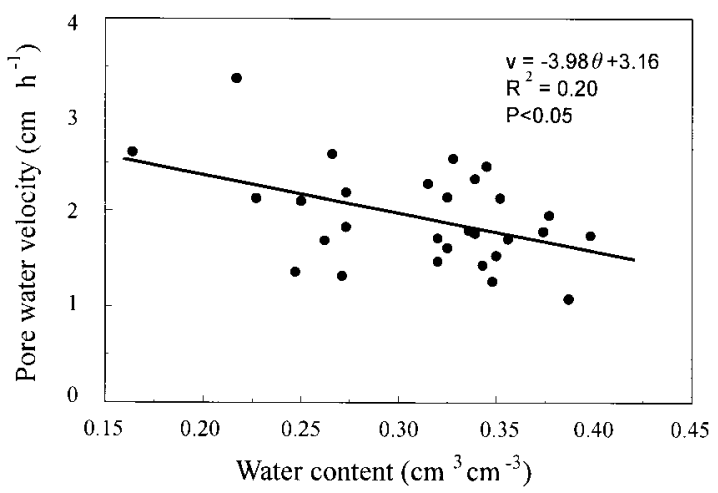

Fig. 6. Pore water velocity vs. water content. 


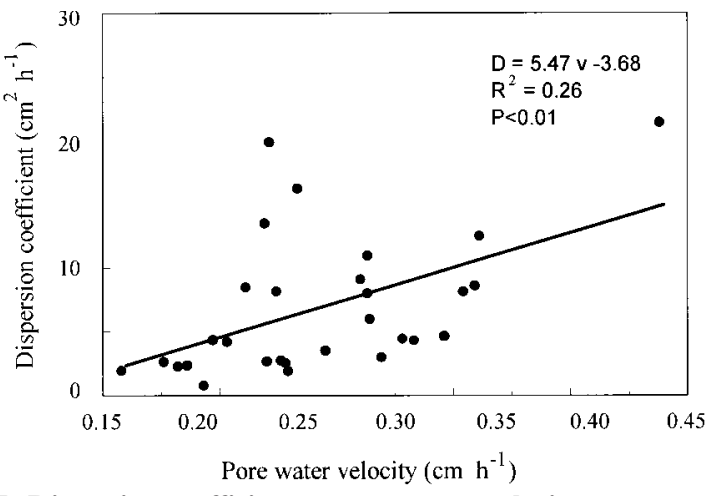

Fig. 7. Dispersion coefficient vs. pore water velocity.

$b$. However, the relationship between $b$ and $D$ was not significant at $P<0.05$. None of the other relationships between the solute transport parameters and soil properties were statistically significant.

\section{CONCLUSIONS}

Analyses of solute transport data from undisturbed, unsaturated soil blocks revealed that the CDE provides an excellent fit to the observed breakthrough curves. This observation is at variance with many recent modeling efforts that have focused on the two-region (MIM) approach. Theoretically, the standard CDE can accommodate macropore flow in structured soil, which can be thought of as just another velocity component in a continuous distribution of pore water velocities. As shown by Parker and van Genuchten (1984), the CDE is capable of fitting solute breakthrough curves for macroporous systems just as well, in some cases, as the MIM model and requires fewer fitting parameters.

Statistically significant linear relationships were found between $\theta$ and the Campbell $b$ parameter, $v$ and $\theta, D$ and $v$, and $D$ and $\theta$. However, no direct relationships were found between any of the soil structural properties and $D$ or $v$. We conclude that structural controls on solute dispersion in unsaturated soils subjected to initial and boundary conditions similar to those in our experiments are likely to be indirect and related to differences in water content at a given flow rate produced by differences in pore-size distribution. More direct relationships between soil structural characteristics and

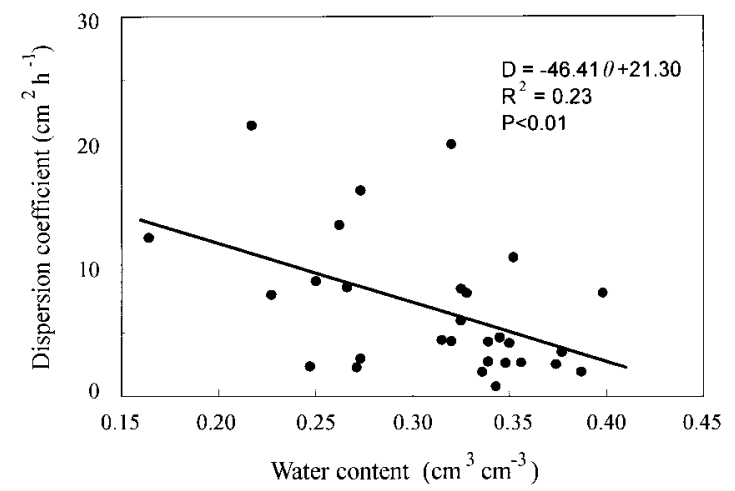

Fig. 8. Dispersion coefficient vs. water content. transport parameters are to be expected under saturated conditions.

The effects of management on preferential flow, and hence solute dispersion, were not appreciable under the conditions of these experiments. The $-2 \mathrm{kPa}$ lower boundary condition ensured that unsaturated conditions were maintained throughout. Under saturated conditions, macropore flow would be expected to significantly increase solute dispersion. The rainfall rate of $\approx 1 \mathrm{~cm}$ $\mathrm{h}^{-1}$ was insufficient to generate any runoff. The occurrence of localized surface runoff could also greatly enhance solute dispersion by channeling water into macropores.

\section{ACKNOWLEDGMENTS}

We appreciate the time and assistance Mike Sukop gave to this project. His expertise with the CXTFIT model was very beneficial to the development of this paper.

\section{REFERENCES}

American Public Health Association. 1989. Standard methods for the examination of water and wastewater. 17th ed. APHA, Baltimore, MD.

Anderson, J.L., and J. Bouma. 1977. Water movement through pedal soils: I. Saturated flow. Soil Sci. Soc. Am. J. 41:413-418.

Andreini, M.S., and T.S. Steenhuis. 1990. Preferential flow paths under conventional and conservation tillage. Geoderma 46:85-102.

Baker, J.M., and R.R. Allmaras. 1990. System for automating and multiplexing soil moisture measurement by time-domain reflectometry. Soil Sci. Soc. Am. J. 54:1-6.

Beven, K.J., D.E. Henderson, and A. Reeves. 1993. Dispersion parameters for undisturbed partially saturated soil. J. Hydrol. 143:19-43.

Biggar, J.W., and D.R. Nielsen. 1976. Spatial variability of the leaching characteristics of a field soil. Water Resour. Res. 12:78-84.

Bowman, B.T., R.R. Brunke, W.D. Reynolds, and G.J. Wall. 1994. Rainfall simulator-grid lysimeter system for solute transport studies using large, intact soil blocks. J. Environ. Qual. 23:815-822.

Bowman, R.S., and R.C. Rice. 1986. Transport of conservative tracers in the field under intermittent flood irrigation. Water Resour. Res. 22:1531-1536.

Brewer, R. 1976. Fabric and mineral analysis of soils. R.E. Kreiger, Huntingdon, New York.

Campbell, G.S. 1974. A simple method for determining unsaturated hydraulic conductivity from moisture retention data. Soil Sci. 117:311-314.

Danielson, R.E., and P.L.Sutherland. 1986. Porosity. p. 443-461. In A. Klute (ed.) Methods of soil analysis. Part 1. Agron. Monogr. 9. ASA, CSSA, and SSSA, Madison WI.

De Smedt, F., and P.J. Wierenga. 1984. Solute transfer through columns of glass beads. Water Resour. Res. 20:225-232.

Dick, W.A., R.J. Roseberg, E.L. McCoy, W.M. Edwards, and F. Haghiri. 1989. Surface hydrologic response of soils to no-tillage. Soil Sci. Soc. Am. J. 53:1520-1526.

Dyson, J.S., and R.E. White. 1987. A comparison of the convectiondispersion equation and transfer function model for predicting chloride leaching through an undisturbed structured clay soil. J. Soil Sci. 37:157-171.

Edwards, W.M., L.D. Norton, and C.E. Redmond. 1988. Characterizing macropores that affect infiltration into non-tilled soil. Soil Sci. Soc. Am. J. 52:483-487.

Edwards, W.M., M.J. Shipitalo, W.A. Dick, and L.B. Owens. 1992. Rainfall intensity affects transport of water and chemicals through macropores in no-till soil. Soil Sci. Soc. Am. J. 56:52-58.

Gist, G.A., A.H. Thompson, A.J. Katz, and R.L. Higgins. 1990. Hydrodynamic dispersion and pore geometry in consolidated rock. Phys. Fluids A 2:1533-1544.

Granovsky, A.V., E.L. McCoy, W.A. Dick, M.J. Shipitalo, and W.M. Edwards. 1993. Water and chemical transport through long-term no-till and plowed soils. Soil Sci. Soc. Am. J. 57:1560-1567. 
Haga, D., Y. Niibori, and T. Chida. 1999. Hydrodynamic dispersion and mass transfer in unsaturated flow. Water Resour. Res. 35:1065-1077.

Hart, G.L., and B. Lowery. 1998. Measuring instantaneous solute flux and loading with time domain reflectometry. Soil Sci. Soc. Am. J. 62:23-35.

Hatfield, M.W. 1988. Water and anion movement in a typic Hapludult. Ph.D. diss., Clemson University, Clemson, SC.

Hillel, D. 1980. Fundamentals of soil physics. Academic Press, San Diego.

Jardine, P.M., G.V. Wilson, and R.J. Luxmoore. 1988. Modeling the transport of inorganic ions through undisturbed soil columns from two contrasting watersheds. Soil Sci. Soc. Am. J. 52:1252-1259.

Jury, W.A. 1982. Simulation of solute transport using a transfer function model. Water Resour. Res. 18:363-368.

Jury, W.A., and G. Sposito. 1985. Field calibration and validation of solute transport models for the unsaturated zone. Soil Sci. Soc. Am. J. 49:1331-1341.

Kay, B.D., and D.E. Elrick. 1967. Adsorbtion and movement of lindane in soils. Soil Sci. 104:314-322.

Klute, A. 1986. Water retention: Laboratory methods. p. 635-662. In A. Klute (ed.) Methods of soil analysis. Part 1. Agron. Monogr. 9. ASA, CSSA, and SSSA, Madison WI.

Klute, A., and C. Dirksen. 1986. Hydraulic conductivity and diffusivity: Laboratory methods. p. 687-734. In A. Klute (ed.) Methods of soil analysis. Part 1. Agron. Monogr. 9. ASA, CSSA, and SSSA, Madison WI.

Kool, J.B., J.C. Parker, and M.Th. van Genuchten. 1987. Parameter estimation for unsaturated flow and transport models - A review. J. Hydrol. 91:255-293.

Matsubayashi, U., L.P. Devkota, and F. Takagi. 1997. Characteristics of the dispersion coefficient in miscible displacement through a glass beads medium. J. Hydrol. 192:51-64.

Nelson, P.A. 1990. Solute movement and root distribution as affected by soil structure. Ph.D. diss., Clemson University, Clemson, SC.

Nielsen, D.R., M.Th. van Genuchten, and J.W. Biggar. 1986. Water flow and solute transport processes in the unsaturated zone. Water Resour. Res. 22:89S-108S

Parker, J.C., and M.Th. van Genuchten. 1984. Determining transport parameters from laboratory and field tracer experiments. Virginia Agric. Exp. Stn. Bull. 84-3. Virginia Polytechnic Inst. and State Univ., Blacksburg, VA.

Phillips, R.E., V.L. Quisenberry, and J.M. Zeleznik. 1995. Water and solute movement in an undisturbed, macroporous column: Extraction pressure effects. Soil Sci Soc. Am. J. 59:707-712.

Poletika, N.N., and W.A. Jury. 1994. Effects of soil management on water flow distribution and solute dispersion. Soil Sci Soc. Am. J. 58:999-1006.
Quisenberry, V.L., R.E. Phillips, and J.M. Zeleznik. 1994. Spatial distribution of water and chloride macropore flow in a well-structured soil. Soil Sci. Soc. Am. J. 58:1294-1300.

Rao, P.S.C., R.E. Jessup, D.E. Rolston, J.M. Davidson, and D.P. Kilcrease. 1980a. Experimental and mathematical description of nonadsorbed solute transfer by diffusion in spherical aggregates. Soil Sci. Soc. Am. J. 44:684-688.

Rao, P.S.C., D.E. Rolston, R.E. Jessup, and J.M. Davidson. 1980b. Solute transport and aggregated porous media: Theoretical and experimental evaluation. Soil Sci. Soc. Am. J. 44:1139-1146.

SAS Institute. 1988. SAS/STAT user's guide. Version 6.03 ed. SAS Inst., Cary, NC.

Seyfried, M.S., and P.S.C. Rao. 1987. Solute transport in undisturbed columns of an aggregated tropical soil: Preferential flow effects. Soil Sci. Soc. Am. J. 51:1434-1444.

Shipitalo, M.J., W.M. Edwards, W.A. Dick, and L.B. Owens. 1990 Initial storm effects on macropore transport of surface-applied chemicals in no-till soil. Soil Sci. Soc. Am J. 54:1530-1536.

Toride, N., F.J. Leij, and M.Th. van Genuchten. 1995. The CXTFIT code for estimating transport parameters from laboratory or field tracer experiments. Version 2. Research Report no.137. U.S. Salinity Laboratory, USDA-ARS, Riverside, CA.

van Genuchten, M.Th., and F.N. Dalton. 1986. Models for simulating salt movement in aggregated field soils. Geoderma 38:165-183.

van Genuchten, M.Th., and P.J. Wierenga. 1986. Solute dispersion coefficients and retardation factors. p. 1025-1054. In A. Klute (ed.) Methods of soil analysis. Part 1. Agron. Monogr. 9. ASA, CSSA and SSSA, Madison WI.

Van Ommen, H.C., M.Th. van Genuchten, W.H. van der Molen, R. Dijksma, and J. Hulshof. 1989. Experimental and theoretical analysis of solute transport from a diffuse source of pollution. J. Hydrol. 105:225-251.

Vervoort, R.W., D.E. Radcliffe, and L.T. West. 1999. Soil structure development and preferential solute flow. Water Resour. Res. 35:913-928.

Walker, P.J.C., and S.T. Trudgill. 1983. Quantimet image analysis of soil pore geometry: Comparison with tracer breakthrough curves. Earth Surf. Processes Landforms 8:465-472.

Wildenschild, D., K.H. Jensen, K. Villholth, and T.H. Illangasekare. 1994. A laboratory analysis of the effect of macropores on solute transport. Ground Water. 32:381-389.

Wraith, J.M., S.D. Comfort, B.L. Woodbury, and W.P. Inskeep. 1993. A simplified waveform analysis approach for monitoring solute transport using time domain reflectometry. Soil Sci. Soc. Am. J. 57:637-642.

Yule, D.F., and W.R. Gardner. 1978. Longitudinal and transverse dispersion coefficients in unsaturated plain field sand. Water Resour. Res. 14.582-588. 